\title{
Utilization of Urine for Cultivation of Selected Vegetable Crops in Backyard "Peeponics"
}

\author{
Mumuni Adejumo*, Chukwudike Igwe, Mynepalli Kameswara Chandra Sridhar \\ Department of Environmental Health Sciences, Faculty of Public Health, College of Medicine, University of Ibadan, Ibadan, \\ Nigeria \\ Email: *adejumo_mumuni@yahoo.com
}

How to cite this paper: Adejumo, M., Igwe, C. and Sridhar, M.K.C. (2019) Utilization of Urine for Cultivation of Selected Vegetable Crops in Backyard "Peeponics". Journal of Environmental Protection, 10, $22-38$.

https://doi.org/10.4236/jep.2019.101002

Received: September 5, 2018

Accepted: January 4, 2019

Published: January 7, 2019

Copyright $\odot 2019$ by author(s) and Scientific Research Publishing Inc. This work is licensed under the Creative Commons Attribution International License (CC BY 4.0).

http://creativecommons.org/licenses/by/4.0/

\begin{abstract}
This study evaluated the use of urine for soilless cultivation (as Peeponics) of Amaranthus viridis and Corchorus olitorius vegetables. This is a laboratory-based experiment involving optimization of amount of urine and dilution required for optimal growth of the test plants. Based on laboratory results, the experiments were scaled up. About $50 \mathrm{~L}$ of raw urine was collected from a male postgraduate student's hall of residence, University of Ibadan, Ibadan, Nigeria. Water from Awba Dam, a natural lake within University of Ibadan, was used as the control. Viable seeds of Amaranthus viridis and Corchorus olitorius were collected from Department of Agronomy, University of Ibadan, and germinated in a nursery for 10 days before transplanting. The raw urine was diluted with varying amount of water in the ratio 1:1 through 1:50. Nutrients in urine media (nitrogen, phosphorus, potassium) and biomass indicators of plant growth (height, weight, number of leaves and leaf area) were determined using standard procedures. Urine dilution ratios below 1:25 did not support the experimental plants growth within a week. Plant height $(\mathrm{cm})$, stem girth $(\mathrm{cm})$, number of leaves (sheets) and leaf area $\left(\mathrm{cm}^{2}\right)$ of Amaranthus viridis and Corchorus olitorius cultivated on Urine Dilution Ratio (UDR) 1:35 and 1:45 were higher at the end of week 3 compared to other dilutions and control. Percentage reduction of nutrients (NPK) in the media of Amaranthus viridis cultivated on UDR 1:45 was several folds higher $(\mathrm{N}=59.9 \%, \mathrm{P}=100 \%, \mathrm{~K}=55.3 \%)$ compared to that of UDR $1: 35(\mathrm{~N}=$ $38.5 \%, \mathrm{P}=49.1 \%, \mathrm{~K}=37.6 \%)$. In the control water, the nutrients were totally removed during the experimental period. Growth of Corchorus olitorius cultivated on both UDR 1:35 and 1:45, was significantly higher at the end of week 6. A significant negative correlation was observed between Corchorus olitorius plant height and Phosphorus $(\mathrm{r}=-0.0418 ; \mathrm{p}<0.05)$ removal in the media. The study concluded that the use of diluted human urine for soilless cultivation of vegetables, if encouraged, could promote food security and environmental sustainability at household level in communities.
\end{abstract}




\section{Keywords}

Human Urine, NPK, Amaranthus viridis, Corchorus olitorius, Peeponics, Backyard Gardening

\section{Introduction}

Indiscriminate disposal of untreated human wastes (urine and faeces) could pollute soil and water sources. This aberration pervades developing countries. The pollution is caused by the phosphorus which is a limiting nutrient in water pollution and eutrophication [1]. Eutrophication leads to algal growths which in turn cause taste and odour problems in drinking water supplies. Dead and decaying algae can also cause oxygen depletion of water bodies which in turn kills fishes and other aquatic fauna in streams [2]. Water pollution is dangerous to the aquatic ecosystems which are primarily used for potable needs of the populations in general and in Nigeria in particular [3]. However, in the developing countries, eutrophication is significant as a result of land-based pollution moving to waters, while human wastes used widely on farmland have been reported as contributing factor to over $80 \%$ of eutrophication worldwide [4] [5] [6] [7]. Eutrophication continues to pose a serious threat to potable water sources, fisheries and recreational water bodies globally [8]. Further, eutrophication also causes hypoxia and anoxia in aquatic life as a result of sedimentation associated with primary production, and reduces the aesthetic quality of water preventing people from recreational activities, like swimming, boating, and picnic [9] [10]. Despite the fact that many people regarded urine as waste, present essential nutrients (nitrogen, phosphorus and potassium) could be recovered using an eco-friendly approach. This approach could improve the surface water quality through reduction of nitrogen and phosphorus inflows from urine into aquatic systems.

Ecological sanitation systems permit the complete recovery of all nutrients in water bodies arising from human activities (e.g. faeces, urine and graywater) benefiting agriculture and allow economical use of water and its maximal reuse. In a study by Höglund, [11] it was reported that urine fraction in domestic wastewater contains about $80 \%$ of the nitrogen, $55 \%$ of the phosphorus and $60 \%$ of the potassium. Therefore, human urine has a potential to substitute chemical fertilizer due to its large amount of these plant nutrients [12]-[17]. These inherent nutrients in human urine could be harnessed through channeling into agricultural activities which would allow recycling of plant nutrients into eco-friendly food production. In addition, engaging in agricultural practice of harnessing nutrients from human urine via "peeponics" can help reduce the menace caused by the influx of human urine into the water bodies leading to eutrophication [18]. In recent years human urine has been widely used as fertilizer to grow tomatoes [16], cabbage [14], cucumber [13], cereal and fruit crops [19] 
[20] and amaranth [21]; still its use in soilless plant cultivation has not been adequately investigated. This study therefore evaluated the use of urine for soilless cultivation (as Peeponics) of Amaranthus viridis and Corchorus olitorius vegetables.

\section{Materials and Methods}

\subsection{Study Area}

University of Ibadan is primarily residential with halls of residence for male and female students at both undergraduate and post-graduate levels. There is water and electricity supply which is also augmented with the inverter system. The Halls of Residence are semi-autonomous. Each Hall of Residence has a Management Committee, which is responsible for matters of general policy for the social, cultural and intellectual activities of the Hall. The halls of residence on the campus are Mellanby Hall (male, undergraduate); Queen Elizabeth II Hall (female, undergraduate); Tedder Hall (male, undergraduate); Sultan Bello Hall (male, undergraduate); Kuti Hall (male, undergraduate); Queen Idia Hall (female, undergraduate); Obafemi Awolowo Hall (female, undergraduate and postgraduate); Nnamdi Azikiwe Hall (male, undergraduate); Independence Hall (male, undergraduate); Tafawa Balewa Hall (mixed, postgraduate) and Abdulsalam Abubakar Hall (mixed, postgraduate). This study was carried out at Abdulsalami Abubakar Hall. The hall (Figure 1) comprises of four (A - D) blocks. Blocks $\mathrm{A}$ and $\mathrm{D}$ are occupied by male postgraduate students while Blocks $\mathrm{B}$ and $\mathrm{C}$ are occupied by female postgraduate students. Each block has 72 rooms (18 rooms per floor) and 56 toilets (14 toilets per floor). Block A and Block B have 216 occupants each, 3 students per room while Block C and Block D have 144 occupants each, 2 students per room.

\subsection{Study Design}

A laboratory-based experiment was carried out in two phases. First phase was an optimization of urine composition for vegetable cultivation. This phase was a pilot study conducted to find out the levels of dilution required for urine that

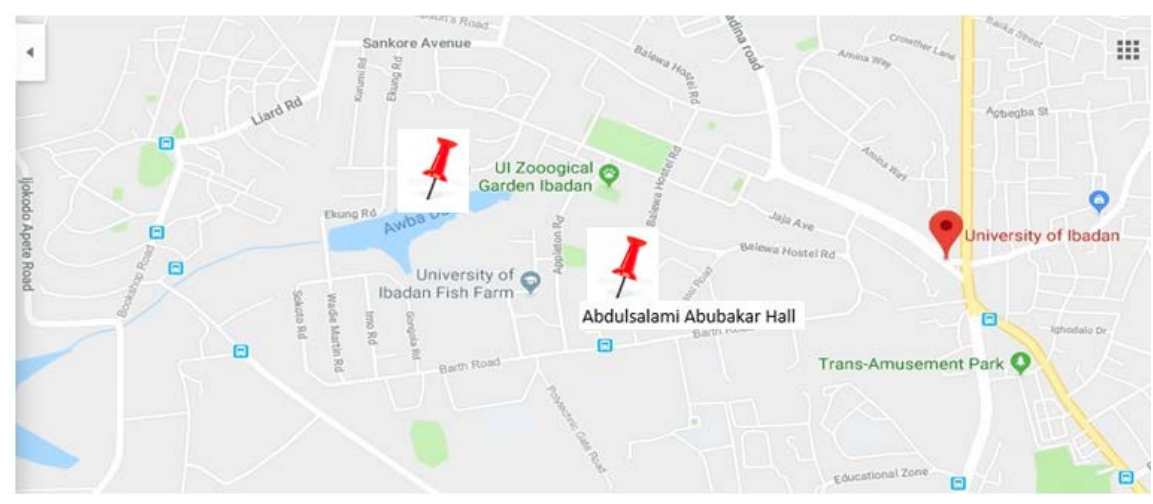

Figure 1. Map of University of Ibadan showing study areas.

Source: https://www.google.com.ng/maps/place/University_of_Ibadan/. 
supports plant growth or the effects of the urine dilutions on plants. The second phase was a scale up laboratory trial of soilless cultivation of Amaranthus viridis and Corchorus olitorius using optimally diluted urine.

\subsection{Obtaining Informed Consent, Collection and Storage of Human Urine}

During the planning stage of the study, the Hall Warden of Abdulsalami Abubakar Hall was approached and informed about the purpose and objective of the study as well as the procedure involved in the collection of urine. Thereafter, the Floor Representatives were contacted and informed that the urine to be collected did not involve individual participants, and that the collected urine would be used to grow vegetables within the Hall. The two meeting sessions were pertinent to ensure that leaders of the hall comprehend all aspects of the study and informed consent sought. Permission was granted by both the Hall Warden and floor representatives to carry out the study and individual postgraduate students were in support of the study. About 50 litres of raw urine was collected from the male postgraduate hall of residence. The container was washed with soap and sharp sand, and properly rinsed with clean water before the sample collection. The urine was collected within 2 days. A plumbing reconstruction was done to channel the urine from the urinals into the collection container (50 litres keg) positioned outside the building after which the facility was fixed back to its original state. Toilet facility urinals that prevented urine from mixing with faeces were also used for the collection of urine.

Urine samples collected were transferred to two 25 -litre kegs with covers. The kegs were tightly covered and stored for two weeks to ensure reduction in toxicity of concentrated urine to plants. This was necessary to ensure health and safety of the inmates. The smell of the stored urine was more pungent when compared with fresh urine. Due to microbial degradation of urea and other components of urine, the colour of the stored urine changed.

\subsection{Collection of Experimental Vegetable Seeds and Nursery Development}

About $10 \mathrm{~g}$ of Amaranthus viridis and $12 \mathrm{~g}$ of Corchorus olitorius were collected from the Agronomy Department, University of Ibadan. The Amaranthus viridis is commonly called Green amaranth (Tete in Yoruba) while Corchorus olitorius is commonly known as Jute mallow (Ewedu in Yoruba). The vegetables are used to prepare special delicacies in Yoruba land. The seeds of Amaranthus viridis and Corchorus olitorius were raised in a nursery using soil (Plate 1) for two weeks before transferring them to the set-up of diluted urine for commencement of the experiment. The nursery area was $1 \mathrm{~m}^{2}$; some seeds were planted inside a bucket (Plate 1(B) and Plate $1(C)$ ) and the nursery bed was irrigated with borehole water once every day in the morning hours. The seeds germinated within 6 to 10 days of sowing. After two weeks of germination, when the seedlings had developed four leaves, the initial agronomic parameters of the seedlings were 

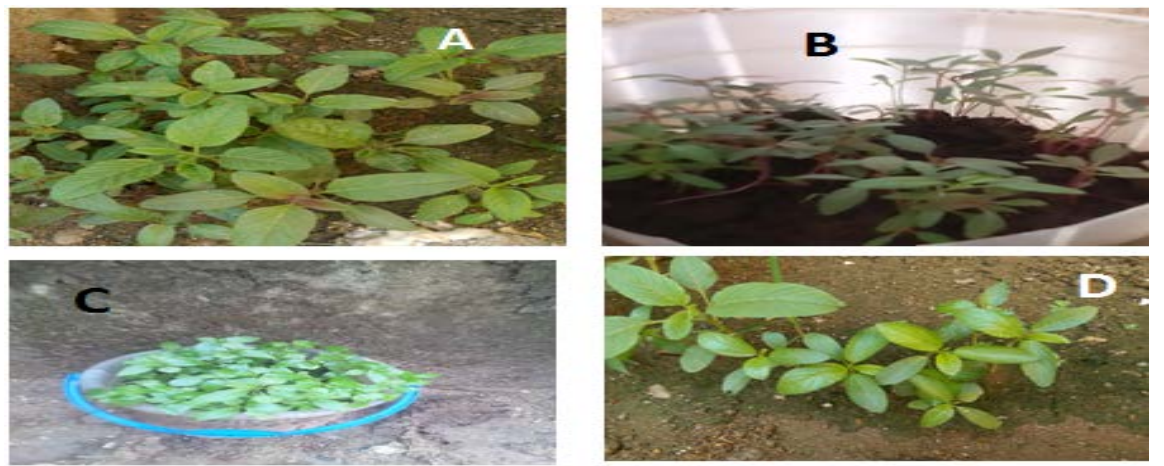

Plate 1. Nursery of Test plants $((\mathrm{A})$ and $(\mathrm{B})=$ Nursery of $A$. viridis $(\mathrm{C})$ and $(\mathrm{D})=$ Nursery of $C$. olitorius).

measured and recorded before transplanting. These agronomic parameters include plant height, number of leaves, stem girth, and leaf area.

\subsection{Collection of the Surface Water to Serve as Control}

Water samples (40 litres) were collected from Awba Dam, a natural lake situated inside the University of Ibadan campus. This water is treated and supplied as drinking water to the university community. In addition it contains sufficient minimal nutrients that may promote plant growth.

\subsection{Experiments with Diluted Urine}

Raw urine has been found to contain high amount of nitrogen, as well as phosphorus and potassium (typically an NPK ratio around 11:1:2.5) and is known to burn up the roots of plants leading to their death [22]. Dilution of raw urine with water becomes expedient to ensure survival of plants when suspended on the diluted urine in a container of llitre capacity. The "Urine to Water" dilution was made using borehole water in varying ratios: $1: 1,1: 2,1: 3$, to $1: 50$ (urine to water). The diluted urine samples were poured into 50 separate transparent containers and replicated. The dilution was repeated for another 1:1 to 1:50, making it up to 100 containers.

\subsection{Experiments Using Diluted Urine under "Peeponics"}

Seedlings of the vegetables were carefully uprooted from the nursery; their roots were washed in clean water by dipping the roots of plants gently into clean water together with soil that came out with the uprooted plants which fell off inside the water. The washed chippings/gravel was poured into the perforated cup half way (Plate 2). Then the uprooted plants were inserted near the corner of the cup, and carefully poured chippings to fill up the cup to be able to hold the plant in place. The shoot system of the plants was not covered with the gravel. It was ensured that chippings/gravel did not break the tender root and stem of the plant while filling up the cup. Some of the long roots were allowed to come out through the perforated holes while others were covered with gravel. The cups 


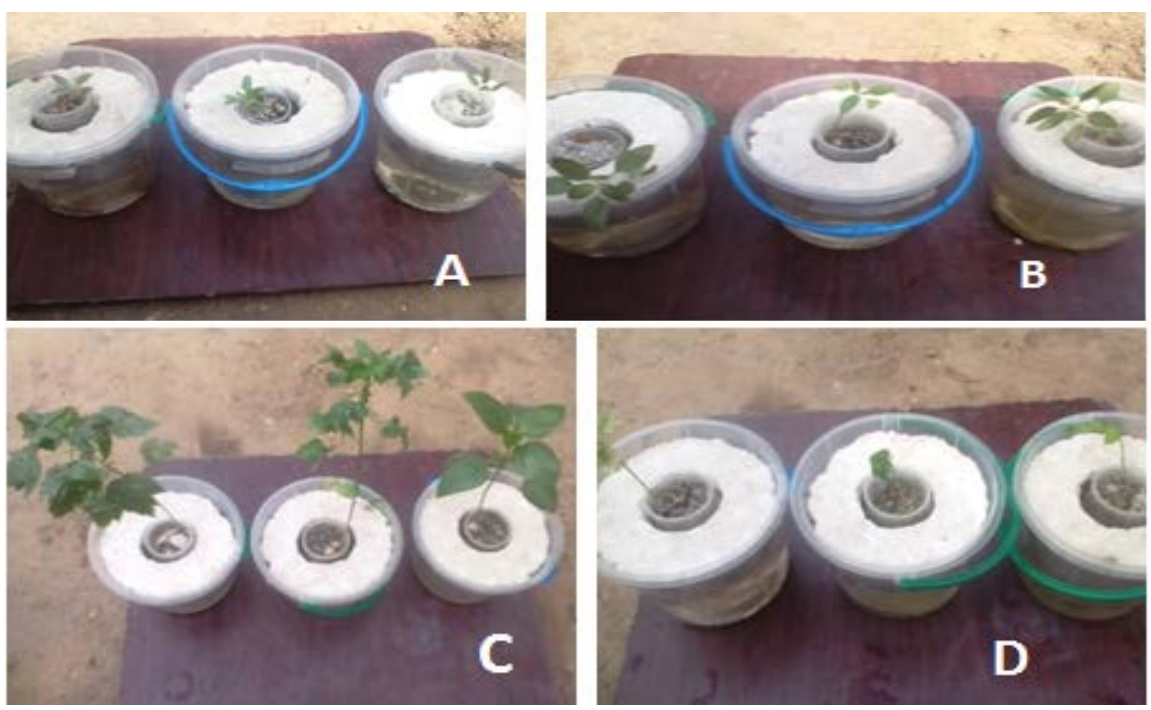

Plate 2. The Experimental ((A) \& (B) = Green Amaranth; (C) \& (D) = Jute mallow). (A) $=$ Green Amaranth on the control water at the end of 6th week of observation; $(B)=$ Green Amaranth on 1:45 Urine dilutions at the end of the 6th week of observation; (C) = Jute mallow on 1:45 Urine dilutions at the end of the 6th week of observation; (D) $=$ Jute mallow on the control water at the end of 6 th week of observation.

were perforated to allow urine to get to the plant roots, and for the plant roots to grow through the perforated holes into the urine as they grew tall. The white Styrofoam was cut round to fit the mouth of the 15-litre bucket to support the plants. Another central hole was cut on the white Styrofoam to allow the perforated cylindrical container to pass through and hold tightly with a grip.

The diluted urine (1:35 diluted) was poured half way into the labeled 15-litre plastic buckets ensuring the perforated cup was not completely immersed inside the urine. The experimental buckets were covered with black nylon to prevent sunlight and the growth of algae inside the containers. The mouths of the buckets were covered with the flat Styrofoam and, the perforated cup that contained the plants was inserted into perforated cylindrical plastic containers and both of them were inserted through the central hole of the white Styrofoam into the buckets containing diluted urine. After watching the level of contact of diluted urine with the cup, extra diluted urine was poured to ensure the cup with the plant was half immersed inside the urine in the bucket. The volume of the urine in the buckets was constant at 15 litres. The two dilution ratios were made in triplicates for each test plant. The setup was in triplicates. The dilution ratio 1:35 was designated Group 1; the 1:45 dilution as Group 2; and Control, Group 3. The entire experiment was monitored biweekly for a period of 6 weeks.

\subsection{Laboratory Analysis}

The $\mathrm{pH}$ was measured using a pre-calibrated $\mathrm{pH}$ meter; Conductivity and total dissolved solids (TDS) were measured using Jenway 470 TDS-Conductivity meter (UK). Total suspended solids (TSS) were determined using gravimetric method. $\mathrm{BOD}_{5}$ was determined based on the difference between the dissolved oxy- 
gen at day one and day 5 after incubation at $20^{\circ} \mathrm{C}$ for 5 days, and multiplied by dilution factor. COD was measured using closed reflux (titrimetric and colorimetric) method using metallic salt reagents. Nitrates was determined using Phenol Disulphonic Acid (PDA) Method. Phosphate was measured by Stannous Chloride Methods while flame photometric was used for the determination of Potassium (K) as described in [23]. These parameters were measured twice in a week consistently during the course of the experiment for a period of six weeks. Appropriate reagent blanks were prepared for each analysis to ensure Quality Control and Quality Assurance. All analyses were carried out in triplicates.

\subsection{Measurement of Agronomic Parameters}

The plant height was measured using meter rule. This measurement was taken from the bottom (stem base) to the tip of the plant in centimetres. Stem girth was measured using Veneer calliper and documented in centimetres. Number of leaves was counted manually. Leaf area was measured using graph sheet to get actual leaf area. This was carried out by tracing the areas covered by the leaf on a graph sheet. This step was done for all the leaves present on the plant and the total area of the leaves divided by the number of the leaves present on the plant at the point of assessment. The leaf area can also be calculated using the formula below:

Plant Leaf Area $=($ Average Estimated leaf Area $) \times($ No. of Leaves $) \times($ Multiplying factor).

Estimated Leaf Area $=($ length of leaf $) \times($ Breadth of Leaf $)$.

Multiplying factor $=($ Actual leaf area/Estimated leaf area $)$ which became a constant for calculating for all the plants. Multiplying factors of each vegetable were calculated.

\subsection{Data Management and Statistical Analysis}

Data were compiled and analysed using statistical package for Social Sciences SPSS (version 21). Data were analysed using descriptive and analytical statistics. The t-test was used to estimate the significant difference between the mean growth rates among two treatment groups. Pearson correlation coefficient was used to quantify the degree of relationship between nutrient clearance from diluted urine and agronomy parameters among the selected vegetables. Analysis of variance (ANOVA) was used to compare the mean results of the two different groups of diluted urine, and controls.

\subsection{Ethical Consideration}

Ethical approval was obtained from the UI/UCH Joint Ethical Review Board to certify both the science and ethics of the research. The Hall Warden of Abdulsalami Abubakar Hall was informed about the objectives of the research and the purpose of collecting urine samples from the urinals located in the male postgraduate hall of residence. The Floor Representatives were also informed that the urine to be collected did not involve any harm but used to grow vegetables 
within the Hall.

\section{Results}

\subsection{Urine Dilution Ratio for Optimal Test Crops Growth}

Values of agronomic parameters within the three weeks were observed and recorded. Changes in the values of the growth media were presented (Figure 2 and Figure 3). Vegetable seedlings planted on urine dilution ratios 1:1 to $1: 25$ did not survive after one week of transplanting. Seedlings planted on UDR 1:30 to 1:50 survived and they were observed for three weeks. The plant height $(\mathrm{cm})$, stem girth (cm), number of leaves (sheets) and leaf areas $\left(\mathrm{cm}^{2}\right)$ of Amaranthus viridis cultivated on UDR 1:35 and 1:45 were higher at the end of week 3 compared to those on other UDRs (Figure 2). Similarly, Corchorus olitorius cultivated on UDR 1:35 and 1:45 had higher plant height $(\mathrm{cm})$, stem girth $(\mathrm{cm})$, number of leaves (sheets) and leaf areas $\left(\mathrm{cm}^{2}\right)$ compared to those planted on other UDRs (Figure 3). This is an indication that the UDRs 1:35 and 1:45 produced vegetables (Amaranthus viridis and Corchorus olitorius) with higher height, stem girth and leaf area and could be chosen as the optimal urine dilution ratio for further scale up study.

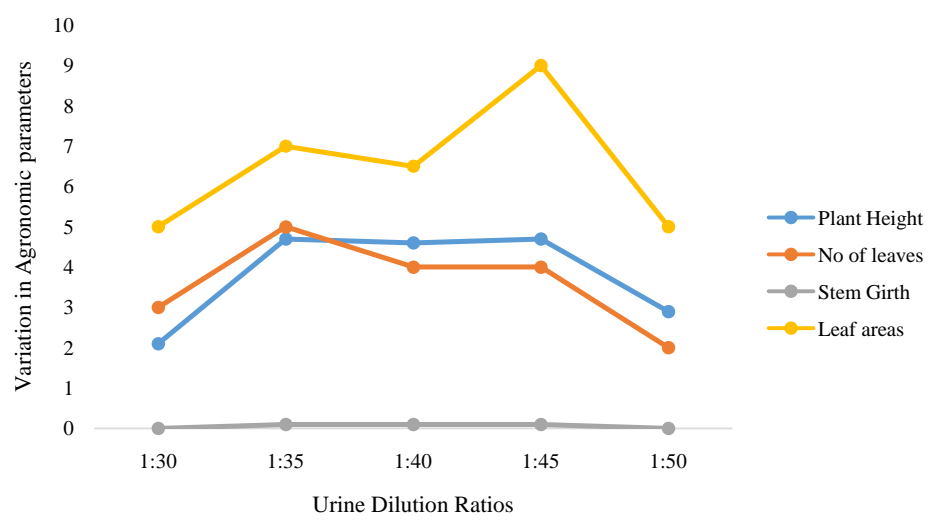

Figure 2. Variation in agronomic parameters of Amaranthus viridis between day 1 and day 21 .

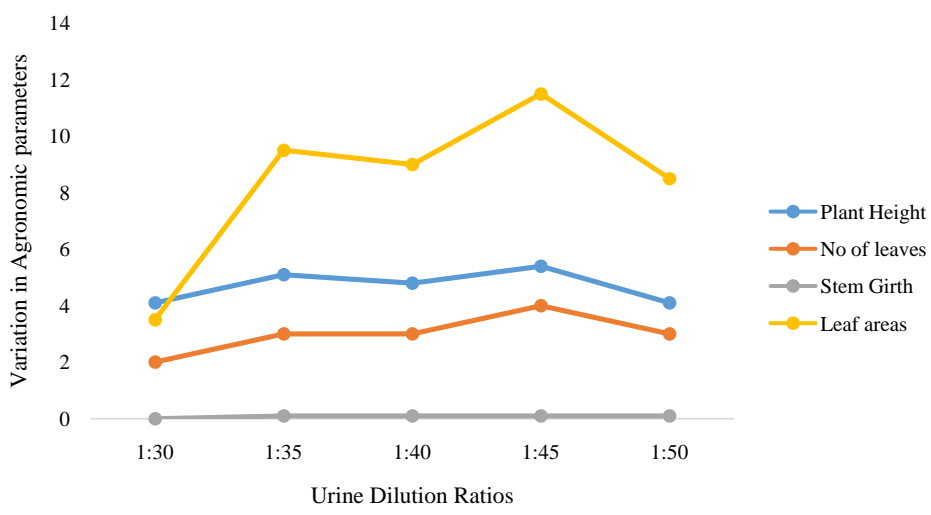

Figure 3. Variation in agronomic parameters of Corchorus olitorius between day 1 and day 21 . 


\subsection{Characteristics of the Diluted Urine}

Diluted urine samples were analyzed before the commencement of vegetable seedlings transplanting. The results are presented in Table 1. The mean $\mathrm{pH}$ (UDR 1:35 vs 1:45) was $6.6 \pm 0.1$ vs $7.3 \pm 0.7$, electrical conductivity ( $\mu \mathrm{s} / \mathrm{cm}$ ) was $85.4 \pm 1.1$ vs $47.3 \pm 0.1$ while Chemical Oxygen Demand $(\mathrm{mg} / \mathrm{L})$ was $41.3 \pm 0.1$ vs $29.8 \pm 1.2$. Mean nitrogen $(\mathrm{mg} / \mathrm{L})$ value was $160.4 \pm 5.85$ (1:35 diluted urine), $130.2 \pm 1.0$ (1:45 diluted urine). Phosphorus $(\mathrm{mg} / \mathrm{L})$ of diluted urine (1:35 vs 1:45) was $13.3 \pm 0.3$ vs $9.1 \pm 0.4$ while potassium $(\mathrm{mg} / \mathrm{L})$ was $40.5 \pm 1.9(1: 35 \mathrm{di}-$ luted urine) and $34.6 \pm 1.6$ (1:45 diluted urine). These results further indicated that the nitrogen, phosphorous and potassium (NPK) values were high in the two urine dilution ratios. The quantities of urine used were adequate to support plant growth. However, UDR 1:35 had higher NPK values compared to UDR 1:45. This was expected since the quantity of dilution solvent (water) in the two UDRs was different.

\subsection{Comparison of Agronomic Parameters of Groups 1:35, 1:45, and Control across Experimental Period}

Comparison of agronomic parameters of the two vegetables (Amaranthus viridis and Corchorus olitorius) cultivated on diluted urine of ratios 1:35 and 1:45, and the control (water) across the period of observation is presented in Table 2. Plant heights of Amaranthus viridis cultivated on urine dilution ratio 1:35, 1:45 and the control were significantly higher at week 6 compared to weeks 1, 2 and 4. Number of leaves of Amaranthus viridis cultivated on urine dilution ratio 1:35 and the control was significant across the 6 weeks of cultivation. However, number of leaves of Amaranthus viridis planted on the diluted urine of ratio 1:45 was not significant at the end of week 6 . This indicated that number of leaves of this vegetable did not increase compared to other agronomic parameters. Stem girths of Amaranthus viridis planted on diluted urine of ratio 1:35 and 1:45 were significant across the six weeks, whereas the vegetables cultivated on the control medium were not statistically significant. Furthermore, leaf area of Amaranthus viridis cultivated on urine dilution ratio 1:35, 1:45 and the control was significant at the end of six weeks of cultivation.

Similarly, plant heights of Corchorus olitorius cultivated on UDR 1:35 and $1: 45$, and the control were significantly higher at the end of week 6 compared to weeks 1, 2 and 4. Number of leaves of Corchorus olitorius cultivated on UDR 1:35 and 1:45, and the control was statistically significant across the 6 weeks of cultivation. Stem girths of Corchorus olitorius planted on diluted urine of ratio 1:35 and 1:45 were statistically significant across the six weeks while the vegetables cultivated on the control medium were not significant. Furthermore, leaf area of Corchorus olitorius cultivated on UDR 1:35, 1:45 and the control was significant at the end of six week of cultivation. These findings indicated that there was a steady increase in biomass as indicated by the agronomic parameters of the vegetables over the cultivation period. It is evident that significant growths of the vegetables were observed with the use of urine during the period of culti- 
vation. Furthermore, concentrations of nitrogen, phosphorus and potassium were compared between urine dilution ratio of 1:35 and 1:45 to establish any differences as presented in Table 3. It was found that the difference between nitrogen of diluted urine on 1:35 and 1:45 that supported Amaranthus viridis cultivation was statistically significant. This is an indication that Amaranthus viridis cultivated on UDR 1:45 reduced nitrogen better than the one planted on UDR 1:35. The mean phosphorus value of dilute urine 1:35 and 1:45 that supported the growth of Amaranthus viridis differed significantly. Diluted urine 1:45 gave the lowest phosphorous value after 6 weeks of cultivating Amaranthus viridis as compared to the diluted urine on 1:35.

Similarly, a statistically significant difference was observed between nitrogen, phosphorous and potassium of diluted urine on ration 1:45 and 1:35 after 6 weeks of Corchorus olitorius cultivation. This indicated that Corchorus olitorius removed higher amounts of nutrients (nitrogen, phosphorous and potassium) from diluted urine 1:45 compared to 1:35.

\subsection{The Percentage Reduction in Nutrients in the Diluted Urine}

While percentage nutrients-NPK reduction of both diluted urine of ratio 1:35 and 1:45 was high after week 6 of cultivating Amaranthus viridis and Corchorus olitorius, nutrients present in UDR 1:45 experienced more reduction compared to those in UDR 1:35 as presented in Table 4. The data revealed that the percentage nitrogen reduction of Amaranthus viridis cultivated on UDR 1:45 was higher (59.9\%) compared to that of UDR 1:35 (38.5\%). Similarly, the percentage phosphorus reduction was $100 \%$ and $49.1 \%$ for UDR $1: 45$ and 1:35 respectively. Percentage reduction of Potassium was high (55.3\%) on Amaranthus viridis cultivated on UDR 1:45 compared to $37.6 \%$ on UDR 1:35. Furthermore, the proportion of nitrogen reduction of Corchorus olitorius was significantly higher $87.2 \%$ at UDR $1: 45$ compared to $52.9 \%$ on UDR 1:35. Percentage phosphorous reductions of Corchorus olitorius on UDR 1:45 and 1:35 were $100 \%$ and $56.6 \%$ respectively. Likewise, potassium was reduced by $86.1 \%$ at a UDR 1:45 and $64.2 \%$ on a UDR 1:35. However, a total Nutrients (NPK) reduction (100\%) was observed in the two vegetables cultivated on the control water.

\subsection{Relationship between Agronomic Parameters of Vegetables and Nutrients (NPK) in the Urine Media}

Correlation between the agronomic parameters of the two vegetables (Amaranthus viridis and Corchorus olitorius) and the nutrients-NPK removals from the media was observed as presented in Table 5. There was a significant negative correlation between Amaranthus viridis plant height and phosphorus ( $\mathrm{r}=$ -0.437, ( $\mathrm{p}<0.01$ ). Similarly, negative correlation existed between Amaranthus viridis plant height and nitrogen $(\mathrm{r}=-0.177)$, and potassium $(\mathrm{r}=-0.316)$. The correlations were not statistically significant $(\mathrm{p}>0.05)$. Also, a statistically not significant negative correlation existed between phosphorus and number of leaves $(r=-0.120)$, stem girth $(r=-0.103)$, and Leaf area $(r=-0.124)$. Likewise, 
there was a statistically significant negative correlation between Corchorus olitorius plant height and Phosphorus $(\mathrm{r}=-0.0418 ; \mathrm{p}<0.05)$. Other indices also revealed negative correlation but were not statistically significant.

Table 1. Characteristics of diluted urine.

\begin{tabular}{cccc}
\hline Characteristics & Dilution 1:35 & Dilution 1:45 & Control (Awba Dam water) \\
\hline $\mathrm{pH}$ & $6.6 \pm 0.1$ & $7.3 \pm 0.7$ & $6.6 \pm 0.1$ \\
Electrical conductivity $(\mu \mathrm{s} / \mathrm{cm})$ & $85.4 \pm 1.1$ & $47.3 \pm 0.1$ & $16.2 \pm 0.2$ \\
Chemical Oxygen Demand $(\mathrm{mg} / \mathrm{L})$ & $41.3 \pm 0.1$ & $29.8 \pm 1.2$ & $6.1 \pm 0.2$ \\
Nitrogen $(\mathrm{mg} / \mathrm{L})$ & $160.4 \pm 5.9$ & $130.2 \pm 1.0$ & $3.2 \pm 0.1$ \\
Phosphorus $(\mathrm{mg} / \mathrm{L})$ & $13.3 \pm 0.3$ & $9.1 \pm 0.4$ & $2.9 \pm 0.2$ \\
Potassium $(\mathrm{mg} / \mathrm{L})$ & $40.5 \pm 1.9$ & $34.6 \pm 1.6$ & $8.3 \pm 0.2$ \\
\hline
\end{tabular}

Table 2. Comparison of agronomic parameters of test plants on urine with dilutions 1:35, 1:45, and Control across the period of Observation.

\begin{tabular}{|c|c|c|c|c|c|c|c|c|}
\hline Plants & Parameters & $\begin{array}{c}\text { Dilutions } \\
\text { (Urine:Water) }\end{array}$ & $\begin{array}{c}\text { At_Start } \\
(\text { Mean } \pm \text { SD })\end{array}$ & $\begin{array}{c}\text { Week } 2 \\
(\text { Mean } \pm \text { SD })\end{array}$ & $\begin{array}{c}\text { Week } 4 \\
(\text { Mean } \pm \text { SD })\end{array}$ & $\begin{array}{c}\text { Week_6 } \\
(\text { Mean } \pm S D)\end{array}$ & $\begin{array}{l}\text { Across period } \\
\text { F statistics }\end{array}$ & p-Value \\
\hline \multirow{12}{*}{$\begin{array}{l}\text { Amaranthus } \\
\text { viridis }\end{array}$} & \multirow{3}{*}{$\begin{array}{l}\text { Plant Height } \\
(\mathrm{cm})\end{array}$} & $1: 35$ & $7.9 \pm 0.2$ & $10.5 \pm 0.7$ & $15.73 \pm 1.00$ & $20.4 \pm 1.54$ & \multirow{3}{*}{$\begin{array}{c}95.943 \\
39.137 \\
4.478\end{array}$} & \multirow{3}{*}{$\begin{array}{c}<0.001 \\
<0.001 \\
0.040\end{array}$} \\
\hline & & $1: 45$ & $8.4 \pm 0.4$ & $12.8 \pm 0.4$ & $18.9 \pm 1.77$ & $25.77 \pm 3.74$ & & \\
\hline & & Control water & $8.2 \pm 0.7$ & $10.1 \pm 1.2$ & $11.23 \pm 1.36$ & $11.4 \pm 1.39$ & & \\
\hline & \multirow{3}{*}{$\begin{array}{c}\text { No of Leaves } \\
\text { (sheets) }\end{array}$} & $1: 35$ & $4.0 \pm 0.00$ & $5.7 \pm 0.6$ & $6.6 \pm 0.58$ & $6.0 \pm 1.00$ & \multirow{3}{*}{$\begin{array}{c}9.267 \\
3.540 \\
25.222\end{array}$} & \multirow{3}{*}{$\begin{array}{c}0.006 \\
0.068 \\
<0.001\end{array}$} \\
\hline & & $1: 45$ & $4.0 \pm 0.00$ & $7.7 \pm 1.5$ & $7.0 \pm 1.73$ & $7.33 \pm 2.08$ & & \\
\hline & & Control water & $4.0 \pm 0.00$ & $6.7 \pm 0.6$ & $4.33 \pm 0.58$ & $3.33 \pm 0.58$ & & \\
\hline & \multirow{3}{*}{ Stem Girth $(\mathrm{cm})$} & $1: 35$ & $0.1 \pm 0.00$ & $0.2 \pm 0.0$ & $0.2 \pm 0.00$ & $0.2 \pm 0.00$ & 443.167 & $<0.001$ \\
\hline & & $1: 45$ & $0.1 \pm 0.00$ & $0.2 \pm 0.01$ & $0.2 \pm 0.01$ & $0.2 \pm 0.01$ & \multirow{2}{*}{$\begin{array}{c}320.333 \\
0.333\end{array}$} & \multirow{2}{*}{$\begin{array}{c}<0.001 \\
0.802\end{array}$} \\
\hline & & Control water & $0.1 \pm 0.00$ & $0.1 \pm 0.01$ & $0.1 \pm 0.01$ & $0.1 \pm 0.01$ & & \\
\hline & \multirow{3}{*}{ Leaf Area $\left(\mathrm{cm}^{2}\right)$} & $1: 35$ & $3.96 \pm 0.64$ & $11.7 \pm 0.6$ & $19.0 \pm 1.4$ & $19.13 \pm 1.45$ & 129.044 & $<0.001$ \\
\hline & & $1: 45$ & $4.5 \pm 0.00$ & $18.2 \pm 1.9$ & $20.37 \pm 1.63$ & $20.9 \pm 1.54$ & \multirow{2}{*}{$\begin{array}{l}81.622 \\
19.088\end{array}$} & \multirow{2}{*}{$\begin{array}{c}<0.001 \\
0.001\end{array}$} \\
\hline & & Control water & $4.29 \pm 4.22$ & $6.5 \pm 0.3$ & $4.37 \pm 1.12$ & $2.53 \pm 0.59$ & & \\
\hline \multirow{12}{*}{$\begin{array}{l}\text { Corchorus } \\
\text { olitorius }\end{array}$} & \multirow{3}{*}{$\begin{array}{l}\text { Plant Height } \\
(\mathrm{cm})\end{array}$} & $1: 35$ & $8.5 \pm 0.50$ & $14.9 \pm 0.3$ & $26.2 \pm 4.88$ & $35.5 \pm 5.71$ & \multirow{3}{*}{$\begin{array}{c}30.410 \\
158.521 \\
14.475\end{array}$} & \multirow{3}{*}{$\begin{array}{c}<0.001 \\
<0.001 \\
0.001\end{array}$} \\
\hline & & $1: 45$ & $8.6 \pm 0.66$ & $19.6 \pm 1.87$ & $35.1 \pm 3.39$ & $51.17 \pm 3.27$ & & \\
\hline & & Control water & $6.8 \pm 1.14$ & $10.6 \pm 1.91$ & $12.9 \pm 0.98$ & $12.9 \pm 0.98$ & & \\
\hline & \multirow{3}{*}{$\begin{array}{c}\text { No of Leaves } \\
\text { (sheets) }\end{array}$} & $1: 35$ & $4.0 \pm 0.00$ & $5.67 \pm 0.58$ & $7.0 \pm 2.00$ & $7.0 \pm 1.00$ & & \multirow{3}{*}{$\begin{array}{l}0.038 \\
0.001 \\
0.023\end{array}$} \\
\hline & & $1: 45$ & $4.0 \pm 0.00$ & $9.33 \pm 1.53$ & $11.0 \pm 1.00$ & $10.33 \pm 2.08$ & \multirow{2}{*}{$\begin{array}{c}4.563 \\
15.884 \\
5.615\end{array}$} & \\
\hline & & Control water & $4.0 \pm 0.00$ & $6.33 \pm 1.53$ & $5.0 \pm 1.00$ & $3.0 \pm 1.00$ & & \\
\hline & \multirow{3}{*}{ Stem Girth $(\mathrm{cm})$} & $1: 35$ & $0.1 \pm 0.00$ & $0.13 \pm 0.06$ & $0.23 \pm 0.06$ & $0.23 \pm 0.06$ & 6.462 & 0.016 \\
\hline & & $1: 45$ & $0.1 \pm 0.00$ & $0.2 \pm 0.01$ & $0.31 \pm 0.03$ & $0.31 \pm 0.06$ & \multirow{2}{*}{$\begin{array}{c}717.333 \\
1.458\end{array}$} & \multirow{2}{*}{$\begin{array}{c}<0.001 \\
0.297\end{array}$} \\
\hline & & Control water & $0.1 \pm 0.00$ & $0.11 \pm 0.01$ & $0.11 \pm 0.01$ & $0.11 \pm 0.01$ & & \\
\hline & \multirow{3}{*}{ Leaf Area $\left(\mathrm{cm}^{2}\right)$} & $1: 35$ & $4.42 \pm 0.14$ & $25.43 \pm 0.74$ & $27.33 \pm 2.89$ & $27.57 \pm 2.65$ & 94.729 & $<0.001$ \\
\hline & & $1: 45$ & $4.38 \pm 0.21$ & $32.43 \pm 0.85$ & $39.87 \pm 2.68$ & $40.5 \pm 2.86$ & \multirow{2}{*}{$\begin{array}{c}215.375 \\
63.099\end{array}$} & \multirow{2}{*}{$\begin{array}{l}<0.001 \\
<0.001\end{array}$} \\
\hline & & Control water & $4.3 \pm 0.19$ & $6.5 \pm 0.20$ & $2.73 \pm 0.59$ & $2.37 \pm 0.50$ & & \\
\hline
\end{tabular}


Table 3. Comparison of nutrients (NPK) levels in urine medium at the end of week 6.

\begin{tabular}{lccccc}
\hline \multirow{2}{*}{ PLANT } & \multirow{2}{*}{ Nutrients } & \multicolumn{2}{c}{ Dilution (Urine:Water) } & \multicolumn{2}{c}{ At 6 weeks } \\
\cline { 3 - 6 } & & $\mathbf{1 : 3 5}$ & $\mathbf{1 : 4 5}$ & $\mathrm{t}$ statistics & $\mathrm{p}$-Value \\
\hline \multirow{2}{*}{$\begin{array}{c}\text { Amaranthus } \\
\text { viridis }\end{array}$} & Nitrogen (mg/L) & $98.7 \pm 1.1$ & $52.2 \pm 1.3$ & 16.995 & $<0.001$ \\
& Phosphorus (mg/L) & $6.8 \pm 0.1$ & $0.4 \pm 0.1$ & 5.599 & $<0.001$ \\
& Potassium (mg/L) & $25.3 \pm 0.8$ & $15.5 \pm 0.2$ & 9.233 & $<0.001$ \\
Corchorus & Nitrogen (mg/L) & $75.6 \pm 0.7$ & $16.7 \pm 1.6$ & 18.343 & $<0.001$ \\
olitorius & Phosphorus (mg/L) & $5.8 \pm 0.1$ & $0.0 \pm 0.0$ & 6.687 & $<0.001$ \\
& Potassium (mg/L) & $14.5 \pm 0.2$ & $4.8 \pm 0.7$ & 8.469 & $<0.001$ \\
\hline
\end{tabular}

Table 4. Percentage reduction in nutrients at six weeks of observation.

\begin{tabular}{|c|c|c|c|c|c|}
\hline Plant & Nutrients & $\begin{array}{c}\text { Dilutions } \\
\text { (Urine:Water) }\end{array}$ & At Start & Week 6 & $\%$ Nutrient reduction \\
\hline \multirow{9}{*}{$\begin{array}{c}\text { Amaranthus } \\
\text { viridis }\end{array}$} & \multirow{3}{*}{$\begin{array}{l}\text { Nitrogen } \\
(\mathrm{mg} / \mathrm{L})\end{array}$} & $1: 35$ & 160.4 & 98.7 & 38.5 \\
\hline & & 1:45 & 130.2 & 52.2 & 59.9 \\
\hline & & Control (water) & 3.2 & 0.0 & 100.0 \\
\hline & \multirow{3}{*}{$\begin{array}{l}\text { Phosphorus } \\
\text { (mg/L) }\end{array}$} & $1: 35$ & 13.3 & 6.8 & 49.1 \\
\hline & & $1: 45$ & 9.1 & 0.0 & 100.0 \\
\hline & & Control (water) & 2.9 & 0.0 & 100.0 \\
\hline & \multirow{3}{*}{$\begin{array}{l}\text { Potassium } \\
(\mathrm{mg} / \mathrm{L})\end{array}$} & $1: 35$ & 40.5 & 25.3 & 37.6 \\
\hline & & $1: 45$ & 34.6 & 15.5 & 55.3 \\
\hline & & Control (water) & 8.3 & 0.0 & 100.0 \\
\hline \multirow{9}{*}{$\begin{array}{l}\text { Corchorus } \\
\text { olitorius }\end{array}$} & \multirow{3}{*}{$\begin{array}{l}\text { Nitrogen } \\
(\mathrm{mg} / \mathrm{L})\end{array}$} & $1: 35$ & 160.4 & 75.6 & 52.9 \\
\hline & & $1: 45$ & 130.2 & 16.7 & 87.2 \\
\hline & & Control (water) & 3.2 & 0.0 & 100.0 \\
\hline & \multirow{3}{*}{$\begin{array}{l}\text { Phosphorus } \\
\text { (mg/L) }\end{array}$} & $1: 35$ & 13.3 & 5.8 & 56.6 \\
\hline & & $1: 45$ & 9.1 & 0.0 & 100.0 \\
\hline & & Control (water) & 2.9 & 0.0 & 100.0 \\
\hline & \multirow{3}{*}{$\begin{array}{l}\text { Potassium } \\
(\mathrm{mg} / \mathrm{L})\end{array}$} & $1: 35$ & 40.5 & 14.5 & 64.2 \\
\hline & & $1: 45$ & 34.6 & 4.8 & 86.1 \\
\hline & & Control (water) & 8.3 & 0.0 & 100.0 \\
\hline
\end{tabular}

Table 5. Correlation between Nitrogen, Phosphorous and Potassium (NPK) levels and agronomic parameters of the two vegetables.

\begin{tabular}{cccccccc}
\hline \multirow{2}{*}{$\begin{array}{c}\text { Agronomic } \\
\text { parameters }\end{array}$} & \multicolumn{3}{c}{ Amaranthus viridis } & \multicolumn{3}{c}{ Corchorus olitorius } \\
\cline { 2 - 8 } Plant Height & correlation & -0.177 & $-0.437^{\star *}$ & -0.316 & -0.259 & $-0.0418^{*}$ & -0.277 \\
& Sig. (2-tailed) & 0.300 & 0.008 & 0.061 & 0.128 & 0.011 & 0.102 \\
\multirow{2}{*}{ No of Leaves } & correlation & 0.001 & -0.120 & 0.046 & -0.151 & -0.263 & -0.101 \\
& Sig. (2-tailed) & 0.996 & 0.486 & 0.792 & 0.380 & 0.121 & 0.556 \\
\multirow{2}{*}{ Stem Girth } & correlation & 0.122 & -0.103 & 0.113 & -0.152 & -0.299 & -0.124 \\
& Sig. (2-tailed) & 0.479 & 0.550 & 0.513 & 0.377 & 0.077 & 0.473 \\
\multirow{2}{*}{ Leaf Area } & correlation & 0.091 & -0.124 & 0.079 & -0.016 & -0.159 & 0.051 \\
& Sig. (2-tailed) & 0.597 & 0.470 & 0.645 & 0.926 & 0.355 & 0.769 \\
\hline
\end{tabular}

${ }^{*}$ Correlation is significant at the 0.01 level (2-tailed). 


\section{Discussion}

The present study showed that at a lower dilution ratio of urine, less than 1:35, seedlings of the two test vegetables withered and could not survive beyond one week of transplanting. Several authors had reported similar findings [22] [24] [25]. Seedlings of Amaranthus viridis and Corchorus olitorius planted on UDR 1:30 to 1:50 survived for three weeks. This might be a resulting effect of probably reduction in $\mathrm{NH}_{4}^{+}-\mathrm{N}$ concentration and/or salinity. These findings concur with Yang et al., [25] that plants in urine medium with 1:50 dilution ratio exhibited a glorious green color, whereas the colour descended to gloomy yellow-green with decrease of dilution ratios. Data from this study revealed that agronomic parameters (plant height $(\mathrm{cm})$, stem girth $(\mathrm{cm})$, number of leaves (sheets) and leaf areas $\left(\mathrm{cm}^{2}\right)$ of Amaranthus viridis and Corchorus olitorius seedlings cultivated on UDR 1:35 and 1:45) were higher at the end of week 3 compared to those on other UDRs. This is an indication that the UDRs 1:35 and 1:45 produced vegetables (Amaranthus viridis and Corchorus olitorius) with higher agronomic parameters and could be chosen as the optimal urine dilution ratio for further study.

The nitrogen, phosphorous and potassium (NPK) values were sufficiently high in the UDR 1:35 and 1:45. The quantities were adequate to support plant growth. The quantity of NPK in this study was higher than the findings of previous study [26]. However, UDR 1:35 had higher amounts of NPK compared to UDR 1:45. This was expected since the amount of diluent (water) was higher in dilution ratio 1:45 compared to 1:35. High quantity of NPK in the two dilution ratios would provide adequate nutrients required for plant growth. This is similar to the findings of Jönsson et al. [26], that the macronutrients such as nitrogen, phosphorous and potassium are frequently required by plant in large proportions than micronutrients. Data from this study revealed that the plant height $(\mathrm{cm})$, number of leaves, Stem girth $(\mathrm{cm})$, and leaf area $\left(\mathrm{cm}^{2}\right)$ of Amaranthus viridis on urine of dilution ratio 1:35 across six weeks were supported by the nutrients in the diluted urine. Likewise the Amaranthus viridis planted on 1:45 dilutions showed increase in all the parameters assessed from the start of the experiment to the sixth week of observation. These increases in parameters observed were supposedly because of the presence of nutrients in urine. The Corchorus olitorius vegetable showed an increase in plant yield over the period of cultivation. This is an indication that urine on dilution ratio 1:35 and 1:45 supported the growth. This findings is similar to the previous studies [27] [28] [29]. This study also found that the Corchorus olitorius vegetable planted on urine of dilution ratio 1:45 produced better yield than Corchorus olitorius planted on the dilution 1:35. This could be attributed to the possibility that the nitrogen concentration in dilution ratio 1:35 posed a little stress on the plant as indicated during the optimization of urine concentration. Furthermore, data from this study indicated that there was a steady increase in the agronomic parameters (plant height, stem girth and leaf area, number of leaves) of both the Amaranthus viridis and Corchorus olitorius vegetables over the cultivation period. This evidence 
suggests that significant growth of the vegetable was observed with the use of urine during the period of cultivation.

The study revealed that the nitrogen level of diluted urine on 1:35 and 1:45 dilution ratios that supported Amaranthus viridis cultivation was reduced by $38.5 \%$ and $59.9 \%$ respectively at the end of the experiment. The phosphorus decreased by $49.1 \%$ in 1:35 dilution; and $100 \%$ in 1:45 dilution. The potassium reduced by $37.6 \%$ in 1:35 dilution; and $55.3 \%$ in 1:45 dilution. All the nutrients in the control were completely exhausted at the end of the experiment. These downward trends indicate nutrient clearance from the soilless medium which was caused by the absorption of the test plant. Similar increase in agronomy parameters which leads to decrease in NPK has been reported [27] [30]. The proportion of nitrogen reduction of Corchorus olitorius vegetable was $87.2 \%$ with UDR 1:45 compared to 52.9\% with UDR 1:35. Phosphorous reduction of Corchorus olitorius vegetable on UDR 1:45 and 1:35 were $100 \%$ and $56.6 \%$ respectively, whereas potassium was reduced by $86.1 \%$ at a UDR $1: 45$ and $64.2 \%$ at a UDR 1:35. However, the total nutrients (NPK) reduction (100.0\%) was observed in the two vegetables (Amaranthus viridis and Corchorus olitorius) cultivated on the control water. These findings corroborate the report of Morgan and Connolly [31] that plant growth and development largely depend on the combination and concentration of mineral nutrients available in the soil or the medium, in this case liquid.

The study found that the Amaranthus viridis vegetables cultivated on UDR 1:45 significantly reduced nitrogen better than the one planted on UDR 1:35. Also, diluted urine of 1:45 ratio significantly gave the lowest phosphorous value after 6 weeks of cultivating Amaranthus viridis as compared to the diluted urine of 1:35 ratio. Furthermore, a statistically significant difference was observed between nitrogen, phosphorous and potassium of diluted urine at ratio 1:45 and 1:35 after 6 weeks of Corchorus olitorius cultivation. This indicated that Corchorus olitorius was capable of removing higher amounts of nutrients (nitrogen, phosphorous and potassium) from diluted urine medium 1:45 compared to 1:35. Furthermore, a significantly negative correlation was observed between Amaranthus viridis plant height and phosphorus, whereas correlation between plant height and nitrogen, and potassium was negative but not significant. Likewise, all the agronomic parameters (plant height, stem girth, number of leaves and leaf area) were negatively correlated with nutrients (NPK) in the diluted urine. These findings, nevertheless, suggest that increase in agronomic parameters indicting biomass increase bring about the reduction in the concentration of the nutrients (NPK) in the diluted urine. Thus urine use as peeponics is a good source of food security in the households with low income.

\section{Conclusion}

This study affirmed that diluted urine contains plant nutrients sufficient to support plant growth. Soilless setup with Urine Dilution Ratios 1:35 and 1:45 pro- 
duced vegetables (Amaranthus viridis and Corchorus olitorius) with increased height, stem girth and leaf area and was chosen as the optimal urine dilution ratio for scaled up laboratory experiments. There was a steady increase in the agronomic parameters of the two vegetables, Amaranthus viridis and Corchorus olitorius, over the six weeks of cultivation. Furthermore, Corchorus olitorius had significantly removed nutrients (nitrogen, phosphorous and potassium) from dilute urine compared to Amaranthus viridis. Nutrients reduction was higher in setup with urine dilution ratio 1:45 compared to 1:35 after week 6 of cultivation. The reduction in nutrients in the urine media used in the experiments was as a result of biomass increase as evident from the agronomic parameters. The use of diluted human urine for soilless cultivation of vegetables as peeponics, if encouraged at household level, could promote food security and environmental sustainability.

\section{Acknowledgements}

Our sincere appreciation goes to Mr. Odueze Christopher Temple for his immense support during the Laboratory analysis of urine samples.

\section{Conflicts of Interest}

The authors declare no conflicts of interest regarding the publication of this paper.

\section{References}

[1] Bartram, J. and Chorus, I. (1999) Toxic Cyanobacteria in Water: A Guide to Their Public Health Consequences, Monitoring, and Management. WHO, London.

[2] Neal, C., Jarvie, H.P., Neal, M., Love, J.A., Hill, L. and Wickham, H. (2005) Water Quality of Treated Sewage Effluent in a Rural Area of the Upper Thames Basin, Southern England, and the Impacts of such Effluents on Riverine Phosphorus Concentration. Journal of Hydrology, 304, 103-117. https://doi.org/10.1016/j.jhydrol.2004.07.025

[3] Aboyeji, O.O. (2013) Fresh Water Pollution in Some Nigerian Local Communities, Causes, Consequences and Probable Solutions. Academic Journal of Interdisciplinary Studies, 2, 111-117

[4] Adeyemo, O.K. (2003) Consequences of Pollution and Degradation of Nigerian Aquatic Environment on Fisheries Resources. The Environmentalist, 23, 297-306. https://doi.org/10.1023/B:ENVR.0000031357.89548.fb

[5] Nwaeze, N. and Onyisi, U. (2011) Phycological Effects of Eutrophication with fertilizers in Nike Lake, Nigeria. Journal of Water Resources and Protection, 3, 856-860. https://doi.org/10.4236/jwarp.2011.312095

[6] Nwanebu, F.C., Ogbuie, J.N., Obi, R.K. and Ojiako, O.A. (2011) Chemical and Salt Induced Eutrophication Syndrome at Otamiri River, Owerri, Nigeria. Journal of Public Health and Epidemiology, 3, 358-361.

[7] Erhunmwunse, N.O., Dirisu, A.R. and Ogbeibu, A.E. (2013) Managing Eutrophication in Nigeria Inland Waters. Journal of Water Resource and Protection, 5, 743-746. https://doi.org/10.4236/jwarp.2013.57075 
[8] Smith, V.H. and Schindler, D.W. (2009) Eutrophication Science: Where Do We Go from Here? Trend in Ecology and Evolution, 24, 201-207. https://doi.org/10.1016/j.tree.2008.11.009

[9] Lundberg, C. (2005) Conceptualizing the Baltic Sea Ecosystem: An Interdisciplinary Tool for Environmental Decision Making. AMBIO, 34, 433-439. https://doi.org/10.1579/0044-7447-34.6.433

[10] Kanu, I., Achi, O.K., Ezeronye, O.U. and Anyanwu, E.C. (2006) Seasonal Variation in Bacterial Heavy Metal Biosorption in Water Samples from Eziama River near Soap and Brewery Industries and the Environmental Health Implications. International Journal of Environmental Science and Technology, 3, 95-102. https://doi.org/10.1007/BF03325912

[11] Höglund, C. (2001) Evaluation of Microbial Health Risks Associated with the Reuse of Source Separated Human Urine. Ph.D. Thesis, Royal Institute of Technology (KTH), Swedish Institute for Infectious Disease Control (SMI), Stockholm.

[12] Kirchmann, H. and Pettersson, S. (1995) Human Urine-Chemical Composition and Fertilizer Use Efficiency. Fertilizer Research, 40, 149-154.

https://doi.org/10.1007/BF00750100

[13] Heinonen-Tanski, H., Sjöblom, A., Fabritius, H. and Karinen, P. (2007) Pure Human Urine Is a Good Fertilizer for Cucumbers. Bioresource Technology, 98, 214-217. https://doi.org/10.1016/j.biortech.2005.11.024

[14] Pradhan, S.K., Nerg, A.M., Sjöblom, A., Holopainen, J.K. and Heinomen-Tanski, H. (2007) Use of Cabbage (Brassica oleracea)-Impacts on Chemical, Microbial, and Flavor Quality. Journal of Agricultural and Food Chemistry, 55, 8657-8663. https://doi.org/10.1021/jf0717891

[15] Pradhan, S.K., Pitkanen, S. and Heinonen-Tanski, H. (2009a) Fertilizer Value of Urine in Pumpkin (Cucurbita maxima L.) Cultivation. Journal of Agricultural and Food Science, 18, 57-68.

[16] Pradhan, S.K., Holopainen, J.K. and Heinonen-Tanski, H. (2009) Stored Human Urine Supplemented with Wood ash as Fertilizer in Tomato (Solanum lycopersicum) Cultivation and Its Impacts on Fruit Yield and Quality. Journal of Agricultural and Food Chemistry, 57, 7612-7617. https://doi.org/10.1021/jf9018917

[17] Pradhan, S.K., Holopainen, J.K., Weisell, J. and Heinonen-Tanski, H. (2010) Human Urine and Wood Ash as Plant Nutrients for Red Beet (Beta vulgaris) Cultivation: Impacts on Yield Quality. Journal of Agricultural and Food Chemistry, 58, 2034-2039. https://doi.org/10.1021/jf9029157

[18] Palmquist, H. and Jönsson, H. (2003) Urine, Faeces, Greywater and Biodegradable Solid Waste as Potencial Fertilizers. Proceedings of the 2 nd International Symposium on Ecological Sanitation, Lübeck, 587-594.

[19] Richert, A., Gensch, R., Jonsson, H., Stenstrom, T.A. and Dagerskog, L. (2010) Practical Guidance on the Use of Urine in Crop Production. SEI, Stockholm.

[20] Sridhar, M.K.C., Coker, A.O., Akinjogbin, I.O., Adeoye, G.O. and Odusan, O. (2003) Urine Harvesting through Institutional Participation: A Nigerian Experiment. Proceedings of the 2nd International Symposium on Ecological Sanitation, 7-11 April 2003, 829-842.

[21] AdeOluwa, O.O. and Cofie, O. (2012) Urine as an Alternative Fertilizer in Agriculture: Effect in Amaranths Amaranthus caudatus Production. Renewable Agriculture and Food Systems, 27, 287-294. https://doi.org/10.1017/S1742170511000512

[22] Sower, K.E. (1992) Spring Nitrogen Application with Point Injection or Top-Dress 
to Optimize Nitrogen Use Efficiency, Yield and Protein in Soft White Wheat. Master's Thesis, Washington State University, Pullman, WA, 114 p.

[23] APHA (2005) Standard Method for the Examination of Water and Wastewater. 21st Edition, America Public Health Association, Washington DC.

[24] Shin, J.Y., Park, S.S. and An, K.-G. (2005) Removal of Nitrogen and Phosphorus Using Dominant Riparian Plants in a Hydroponic Culture System. Journal of Environmental Science and Health, Part A, 39, 821-834. https://doi.org/10.1081/ESE-120027744

[25] Yang, L., Giannis, A., Chang, V.W.-C., Liu, B., Zhang, J. and Wang, J.-Y. (2015) Application of Hydroponic Systems for the Treatment of Source-Separated Human Urine. Ecological Engineering, 81, 182-191. https://doi.org/10.1016/j.ecoleng.2015.04.013

[26] Jönsson, H., Richert, S.A., Vinnerås, B. and Salomon, E. (2004) Guidelines on the Use of Urine and Faeces in Crop Production. EcoSanRes Publications, Stockholm.

[27] Muhammad, R., Zhang, P., Shen, H.-L. and Salahuddin (2017) Influence of Nitrogen and Phosphorus on the Growth and Root Morphology of Acer mono. PLoS $O N E, 12, \mathrm{e} 0171321$.

[28] Nafiu, A.K., Togun, A.O., Abiodun, M.O. and Chude, V.O. (2011) Effects of NPK Fertilizer on Growth, Drymatter Production and Yield of Eggplant in Southwestern Nigeria. Agricultural and Biology Journal of North America, 2, 1117-1125. https://doi.org/10.5251/abjna.2011.2.7.1117.1125

[29] Okonwu, K. and Mensah, S.I. (2012) Effects of NPK (15:15:15) Fertilizer on Some Growth Indices of Pumpkin. Asian Journal of Agricultural Research, 6, 137-143. https://doi.org/10.3923/ajar.2012.137.143

[30] Aina, E., Prinzenberg, H.B., David E.S., Benjamin, S. and Matthieu, R. (2010) Relationships between Growth, Growth Response to Nutrient Supply, and Ion Content Using a Recombinant Inbred Line Population in Arabidopsis. Plant Physiology, 154, 136-137.

[31] Morgan, J.B. and Connolly, E.L. (2013) Plant-Soil Interactions: Nutrient Uptake. Nature Education, 4, 2. 